\title{
Studies on Algal Biodiversity of Tapti River in Burhanpur District of Madhya Pradesh, India
}

\author{
Iftekhar A. Siddiqui \\ M.sc, M.Ed. , DMLT, M.Phil, Ph.D (Scholar) Professor \& H.O.D. , Botany Deptt., (U.G \& P.G Level) \\ Professor, S.G.J.Quaderia College, Burhanpur, M.P., India
}

\begin{abstract}
The present investigation was undertaken with a view to saudy algal biodiversity of Tapti river in Burhanpur Distric of Madhya Pradesh, India. The research Work was performed during june 2015 to May 2017, Altogether 26 genera were indentified and recorded from different to sites of Tapti river during the two year period of investigation.of these 13 genera belonged to chlorophyceac 06 genera belonged to Becillariophyeeac, 04 genera belonged to eyanophyeeac, 02 genera belonged to charophyeeac and ol genera belonged to Euflenophyeeac. The members of chlorophyeeac were dominant followed by becillariophyeeac, charophyeeac and euglenophyeeac. Diversity of algae in terms quantity and quality were observed at all selected sites of Tapti river. Unicellular, colonial and filamentous algal forms were reported throughut the period of investigaton. The algal gehera whose specirs recorde at all sites of study area were sjzivogyra, zygnemo cosmarium, Nit ${ }_{3}$ sehia, Euglena, Chlorococcus, oscillatoria and shormidium (see table :1 \& table:2)
\end{abstract}

Keywords: Algal Biodiversity, Algal blooms, Burhanpur, Tapti river, Madhya Pradesh , India

\section{Introduction}

Algal are the most widespread and abundant photosynthetic life in aquatic as well as terrestrial ecosystem. Algae gain its importance in the modern time not only as alternative potential source of protein for the hungry man but also as the primary solirec \& food for equatic animals. Palmer (1969), Trivedy and goel (1980) have reported different algal forms as an indicator of waat pollution.

The accumulation of algae at or heat source $f$ the water is called as "Algal Blooms" or "mats" riew f literature reveals that the algal biodiversity in East Nimar is still in infacy. Therefore to fulfil this lacuna, it has been dicided to work on algal biodiversity of Tapti river in Burhanpur Distric of Madhya Pradesh, India.

\section{Materials and Methods}

Fortnightly collection of water sample was done from all the 10 Sites ( Before samshan ghat $\left[\mathrm{S}_{1}\right]$ Tapti river $\left[\mathrm{S}_{10}\right]$ ) of Tapti river in Burhanpur, M.p India (Sec table:1) Physiochemical parameters where analyzed wing standard methods of APHA (1998) and Khanna and Bhuliai (2008). The algal sample collection carried out with the help of truneate eone shape plankton net the plankton net is made of bolting Silk No. 25 Standard grade. This has aperture size of $0.64 \mathrm{~mm}$. The Sample Was eoncentrated by Sedimentation method, removing this Supernatant by decanting and the desired final volume was obetained . For eounting, $1 \mathrm{ml}$ of Eoncentrated sample was taken and placed Sedgwick Rafter Counting cell following the Standard methods of APHA (1998).Trivedi And Goel (1986) hut Chinson (1967) and Khanna and Bhutiani (2008) The Eoncentrated was preserved in U\% Formatin for study (Wetch,1952). (See Table:1 \& Table:2) Given Formula is used to calculate percentage.

\section{Percent $=$ No. of gener $\times 100$ Total No. of genera}

Table: Sample Collected from to different Sites location.

\begin{tabular}{|c|c|c|c|}
\hline S.No. & Sourec & Sample Location & Sites \\
\hline 01 & Tapti river & Before Samshn ghat & $\mathrm{S}_{1}$ \\
\hline 02 & Tapti river & Shamshan ghat & $\mathrm{S}_{2}$ \\
\hline 03 & Tapti river & Nagzhiri ghat & $\mathrm{S}_{3}$ \\
\hline 04 & Tapti river & Rajghat & $\mathrm{S}_{4}$ \\
\hline 05 & Tapti river & Jainabad Bridge & $\mathrm{S}_{5}$ \\
\hline 06 & Tapti river & Satiyara ghat-1 & $\mathrm{S}_{6}$ \\
\hline 07 & Tapti river & Satiyara ghat-2 & $\mathrm{S}_{7}$ \\
\hline 08 & Tapti river & Big Pool Bridge & $\mathrm{S}_{8}$ \\
\hline 09 & Tapti river & Small Pool Bridge & $8_{9}$ \\
\hline 10 & Tapti river & After Small Pool & $8_{10}$ \\
\hline
\end{tabular}

Table 2: Algal genera common 4 in water habitat of Tapti river in Burhanpur. Distric of Madhya Pradesh, India

\begin{tabular}{|c|c|c|c|c|}
\hline S.No & Name of Algae / genera & Class & \begin{tabular}{|c|}
$\begin{array}{c}\text { Total No. of } \\
\text { genera }\end{array}$ \\
\end{tabular} & $\begin{array}{c}\text { Percentage } \\
\%\end{array}$ \\
\hline 01 & $\begin{array}{c}\text { Chlorella, Cosmarium, oedogonium,Pediastum,scendesmus,Spirogyra, } \\
\text { Ulothrix,Hydrodictyon,Chladophora,Ehloroeoccus,Desmidium, 3ygnema, and } \\
\text { volvox }\end{array}$ & Chlorophyeeac & 13 & 50.0 \\
\hline 02 & Navicula, Nitzsehia, Fragilaria, Pinnularia, Cymbelola. And eyelotella. & Becillariophyeeac & 06 & 23.7 \\
\hline 03 & Oscillatoria, Spirulina, Nostoc, Phormidium & Eyanophyeeac & 04 & 15.3 \\
\hline 04 & Chara, Nitella & Charophyeeac & 02 & 7.6 \\
\hline 05 & Euglena & Euglenophyeeac & 01 & 3.8 \\
\hline Total & 26 & 05 & 26 & 100.4 \\
\hline
\end{tabular}




\section{International Journal of Science and Research (IJSR) \\ ISSN (Online): 2319-7064}

Index Copernicus Value (2016): 79.57 | Impact Factor (2015): 6.391

\section{Results and Discussions}

The information on algal biodiversity is essential in monitoring and management of a aquatic ecosystems.

The result \& Discussions are summarized as below:-

- In present study overall 26 genera were record from five groups of algae i.e chlorophyeeac, Bacillariophyeeac, eynophyeeac, charophyeeac and eliglinophyeeac.

- Chlorophyeeac group Was dominant as it was represent by (13) genera, Becillariophyceeac(06) genera, eyanophyeeac (4) genera, charophyeeac (2) genera and euglenophyeeac (01) genera. (See Table:2)

- The composition of chlorophyeeac was greater in genera composition as compered to the other group of algae.

- Class wise parcentage contribution study of algal genera reveals that light contribution was of chlorophyeeac $(50.0 \%)$ followed by Becillariophyeeac (23.7\%) eyanophyeeac (15.3\%), chlorophyeeac (7.6\%) and euglenophyeeac (3.8\%).(See Fig:1 \& Fig:2)

- During present inventigation it is observed that algal bloom formation starts in ther month of September reaching a peak in the month of November to January . The blooms exists up to may.

- Algal genera of 10 selected sites of Tapri river is very rich and it is found in diverse form. (See Table:1:)

\section{Conclusion}

\section{- Algae Biodiversity Composition:}

In present investigation algal genera such as vos marium, spirogura, sechedesmus, zygnema, ulothrix, pediastum, phoromidium, ascillatoria, spirulina, Fragilaria pinnularia, and eulena were dominant.

- Seasohal Variation:

Winter and slimmer reasons are found favocrable for the growth of algae.

- Pollution index:

For Pollution index study, Pollution tolerant genera of algae were recoarded from all Sites of Study area. The Pollution tolerant genera which were recorded at all sites are euglena, Oscillatoria, Secnedesmus, promidium, spirogyra, and cosmarium.

- Algal genera of satnding and running water habitals: Maximum algal forms were found at stauding water sites as compared to running water sites.

- Algal Blooms:

Algal blooms are cladophara, zygnema, Oscillataria, phormidium and hydrodictyon

- Epiphytic Algal:

Algae epiphytic on aquatic angiosperms like cyperus sp. ipomoea sp. And Typha sp. Were collected and observed. Ex. Ulothrix, Oedogonium pinnularia,

\section{Acknowledgement}

Most humbly I express my profound sence of gratitude to my extcemed supervisor Dr. Suchi Modi ( Botony research Deptt., AISECT UNIVERSITY, BHOPAL, MP.) and patrons Dr. Taiyyeb Saifee, Prof M.H. Saleem Co Supervisor Dr. (Smt.) Jagriti Tripati (Unique College) suggesting me this topic and her / his excelled and intellectual guidance and excellent supervinsion. Graciously I render my sincere thanks to him / her for providing all the necessary guidance and things, Laboratory and library Facilities.

I take this as an golden chance of express my deep depth of regards to Dr. Sangeeta Jouhari ( Faculty Management and convener - Research programe, AISECT UNIVERSITY, BHOPAL, MP.) For giving all the encouragement and guidance, Support and keem attention that you have given as during the study and the prosecutions of the Ph.D course work. It is my moral obligation to offer my thanks to all the members of the staff of AISECT UNIVERSITY, BHOPAL,MP, INDIA.)

I am very much thankfull to hon. Ali Asgar Takliwala (Secretary) and director Prof. M.H Saleem (Patron), S.G.J QUADERIA COLLAGE, BURHANPUR,MP.(QUADERIA EDUCATIONAL AND CULTURAL SOCIETY M.P.) for Permitting meto carry out these Studies.

I am greatful to respected Director Prof. M.H.Saleem Principal Prof. Dr. M.I.R Khan, Prof. Dr.(Smt.) R.K George (H.O.D.) Prof. Shaikh Mohammad (H.O.D), Prof. Dr. Shakil Ahmed (H.O.D) and staff members of botany Deptt. S.G.J QUADERIA COLLAGE, BURHANPUR,MP. For their valuable Suggestions and parental care, encouragement Support.

The Cooperation extended by all my friends. Well wishers are gratefully acknowledged.

\section{References}

[1] APHA , "Standard methods for the examination of water and west water", American Public Health Association, Inc. New York. $18^{\text {th }}$ Ed, 1998.

[2] Ansari ziya and Nandan S.N., "Study of Eutrophication of algal Biodiversity of mausam river". Plant Diversity and biotechnology, PP:17-18.2005.

[3] Hutchinson, G.E., " Introduction to lake biology and limnoplankton." A treatise on limnology vol. II. New York, John Wiley and sons, PP 1115,1967.

[4] Khanna, D.R. and Bhutiani, R. " Ecologycial status of sitapur pond at hardwar (Uttanchal). India." Indian J. Environ. and Ecoplan 7 (1):PP 175-178,2008.

[5] Khare, B.and Patil,P. "Indain Hydrobiology" Journal Chennai 14 (1): PP 8-21,2011.

[6] Trivedy, R.K, and Goel, P.K. " Chemical and biological methods for water pollution studies". Env. Publictions, Karad, India, 1986.

[7] Wetch, P.S., "Limnology." $2^{\text {nd }}$ Ed. Mc Gram Hill Book co., Inc., 1-538,1952.

\section{Author Profile}

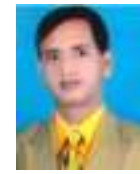

Iftekhar A.Siddiqui did M.sc, M.Ed. , DMLT, M.Phil, Ph.D (Scholar) Professor \& H.O.D. , Botany Deptt., (U.G \& P.G Level) Professor, S.G.J.Quaderia College, Burhanpur, M.P., India 


\title{
International Journal of Science and Research (IJSR) \\ ISSN (Online): 2319-7064
}

Index Copernicus Value (2016): 79.57 | Impact Factor (2015): 6.391

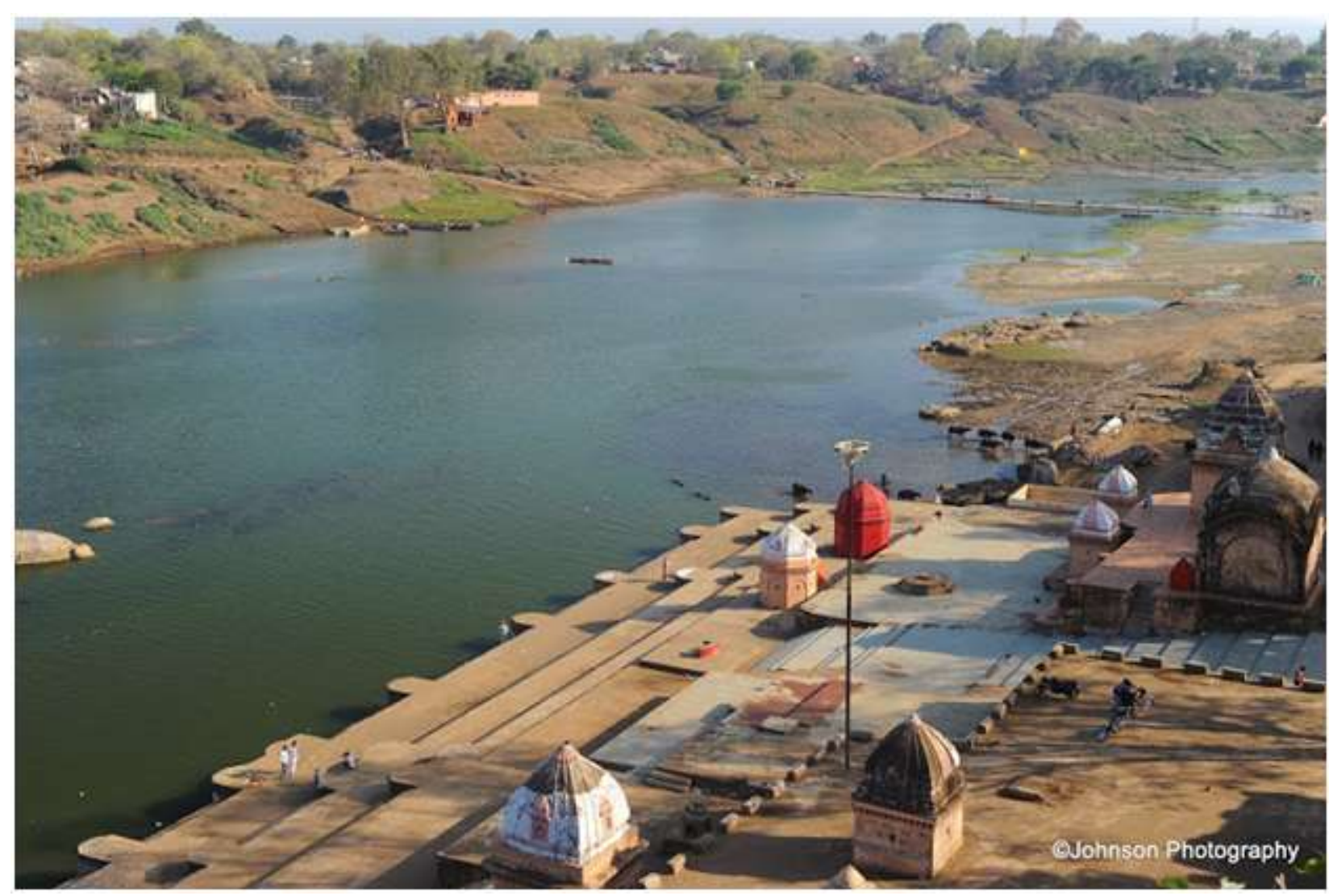

Tapti River Showing Selected Sites (Before Shamshan Ghat S1 To After Small Bridge S10)

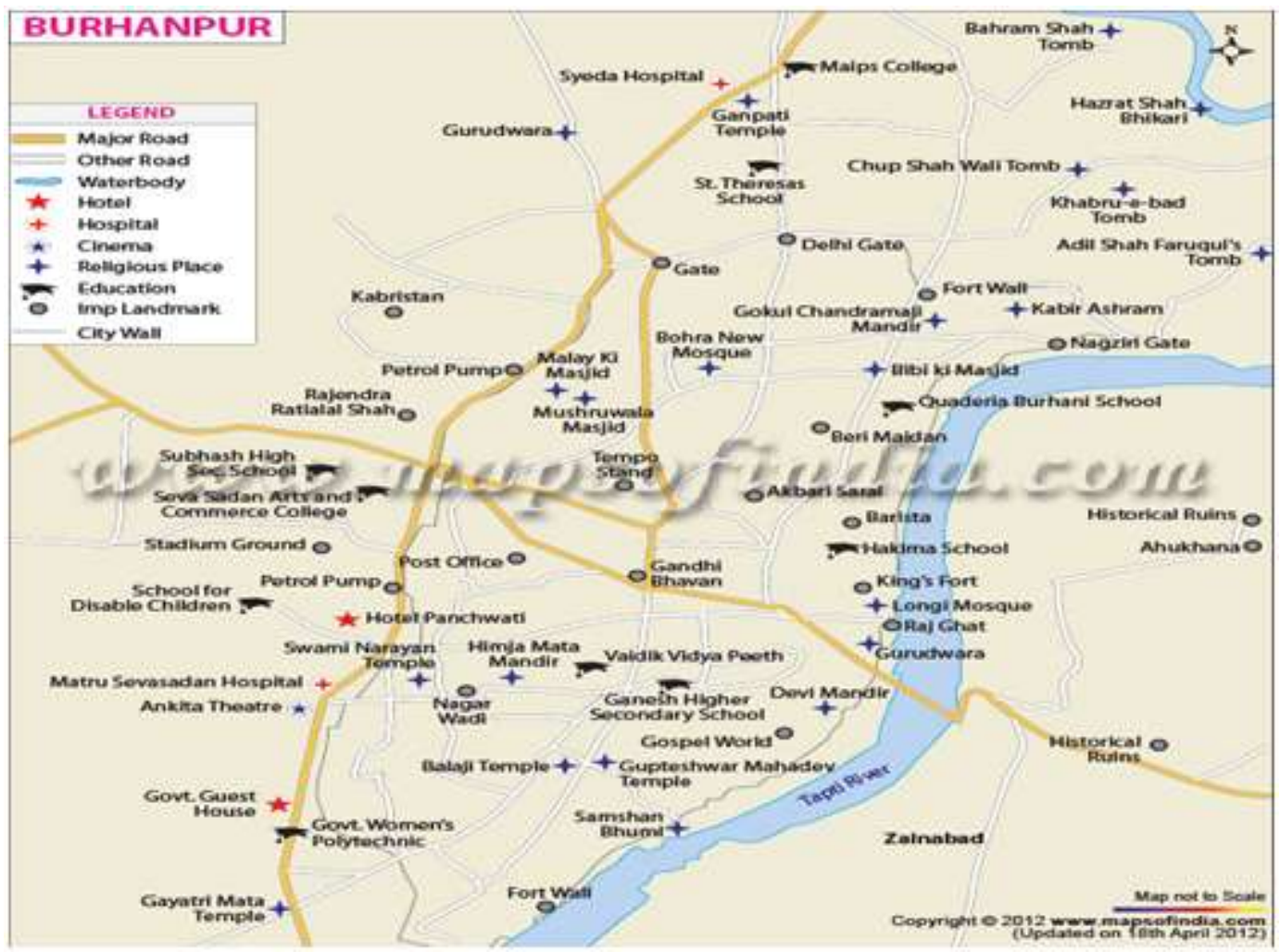

Map of District Burhanpur Showing Sampling Sites (S1 To S10) in Tapti Rever

Volume 6 Issue 12, December 2017

\author{
www.ijsr.net
}

Licensed Under Creative Commons Attribution CC BY 
International Journal of Science and Research (IJSR)

ISSN (Online): 2319-7064

Index Copernicus Value (2016): 79.57 | Impact Factor (2015): 6.391

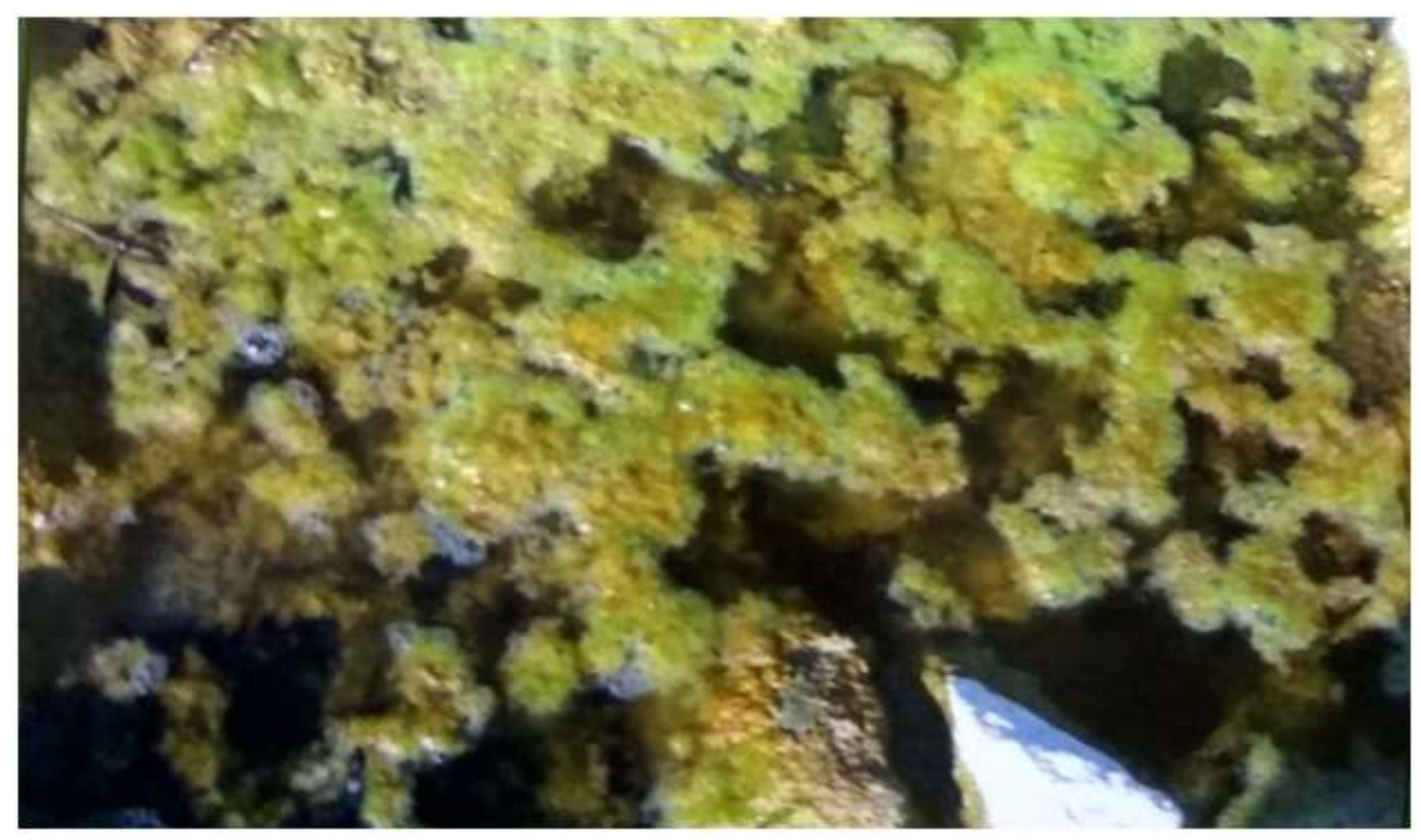

Algal Blooms

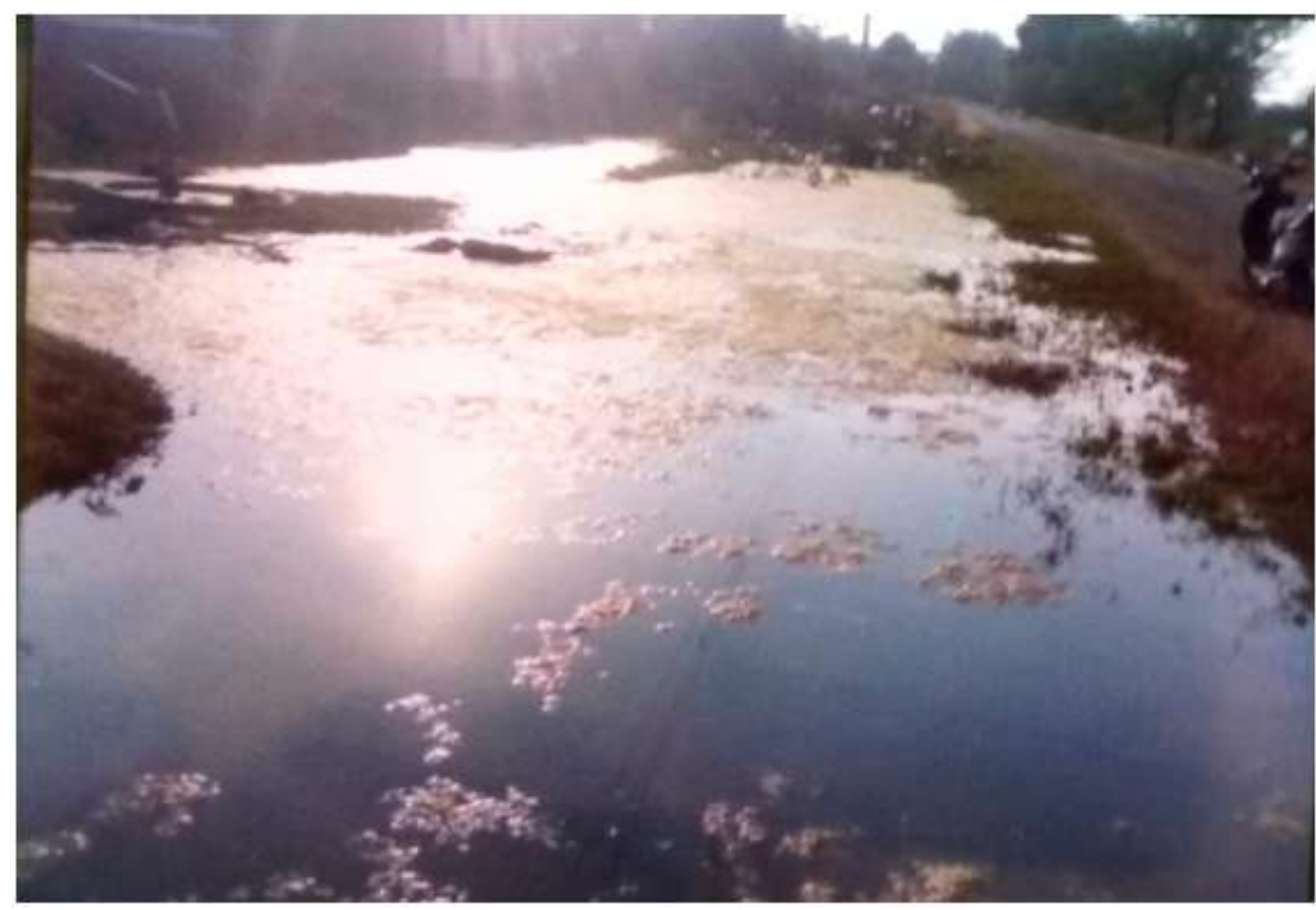

Floating Algae

Volume 6 Issue 12, December 2017

www.ijsr.net

Licensed Under Creative Commons Attribution CC BY 
International Journal of Science and Research (IJSR)

ISSN (Online): 2319-7064

Index Copernicus Value (2016): 79.57 | Impact Factor (2015): 6.391

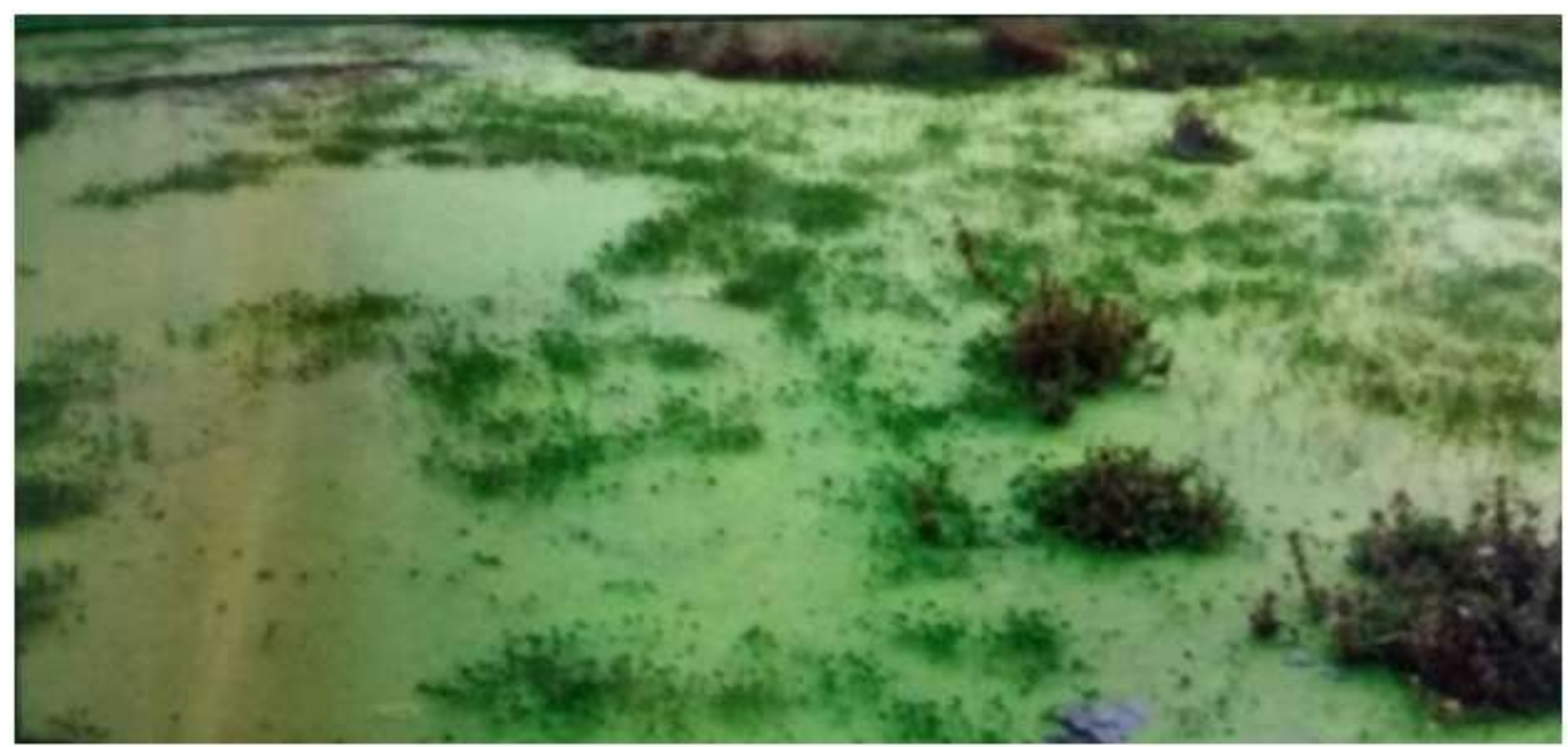

EPIPHYTIC ALGAE

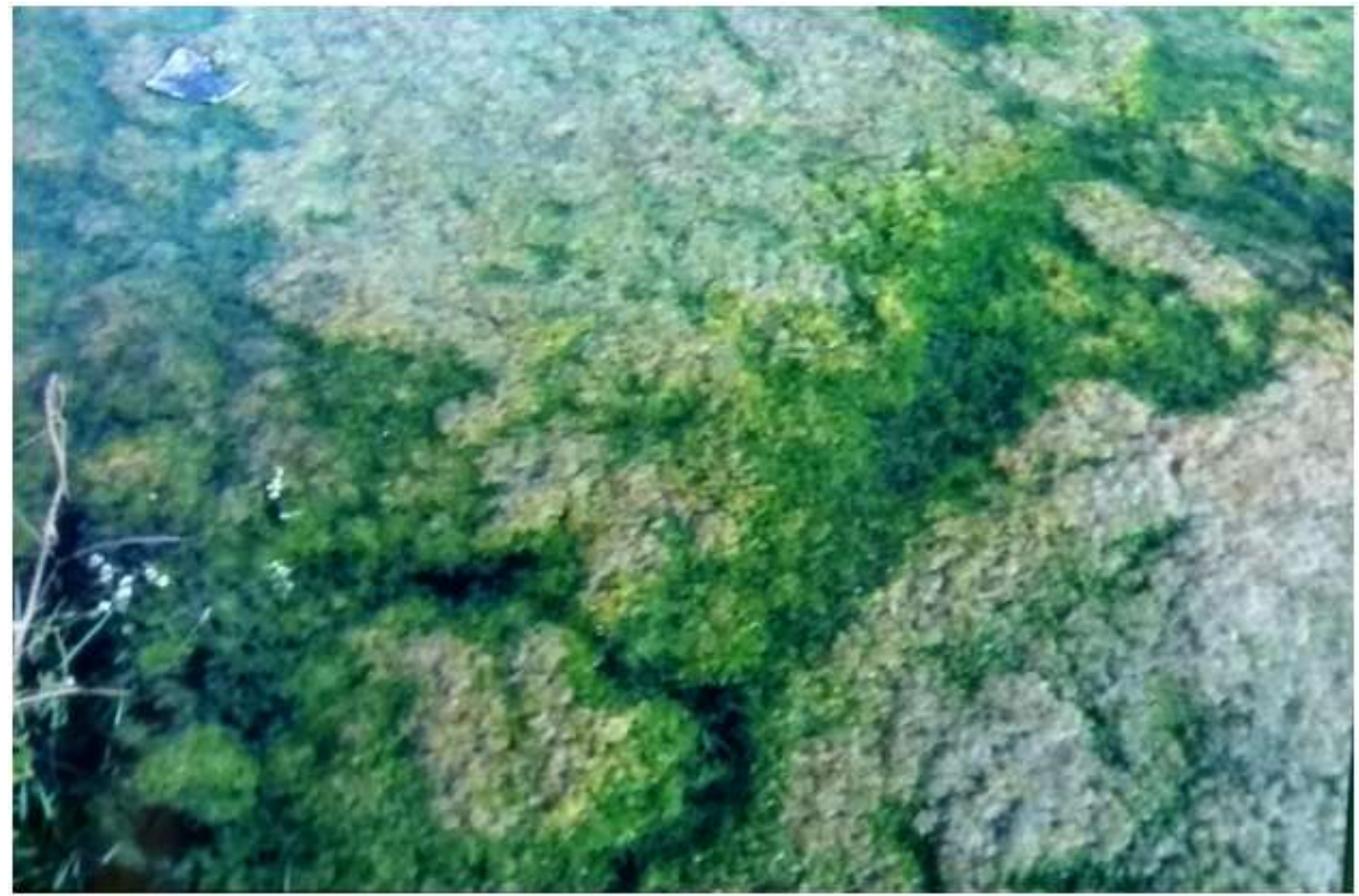

ALGAL POLLUTION

Volume 6 Issue 12, December 2017

www.ijsr.net

Licensed Under Creative Commons Attribution CC BY 
International Journal of Science and Research (IJSR)

ISSN (Online): 2319-7064

Index Copernicus Value (2016): 79.57 | Impact Factor (2015): 6.391
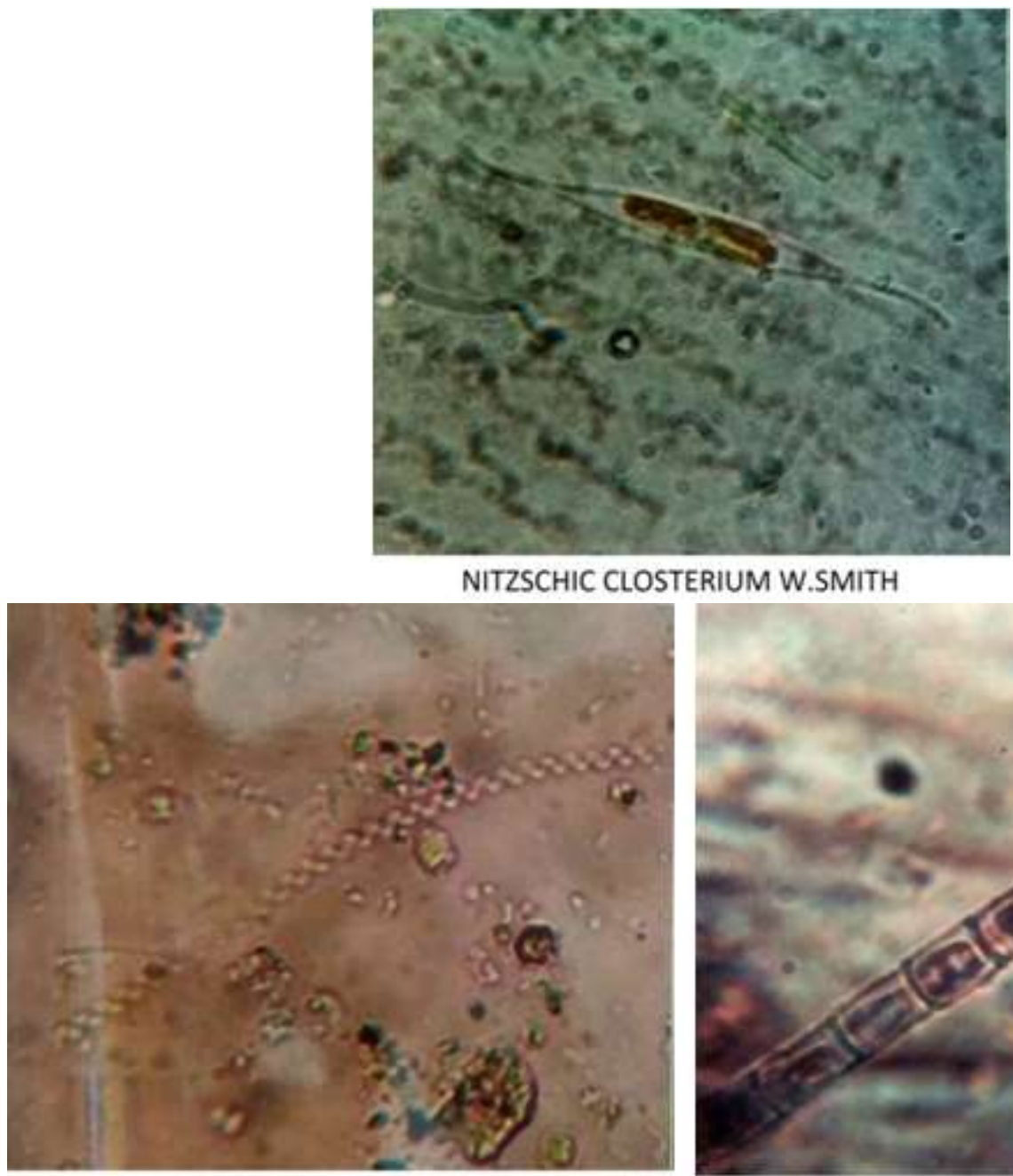

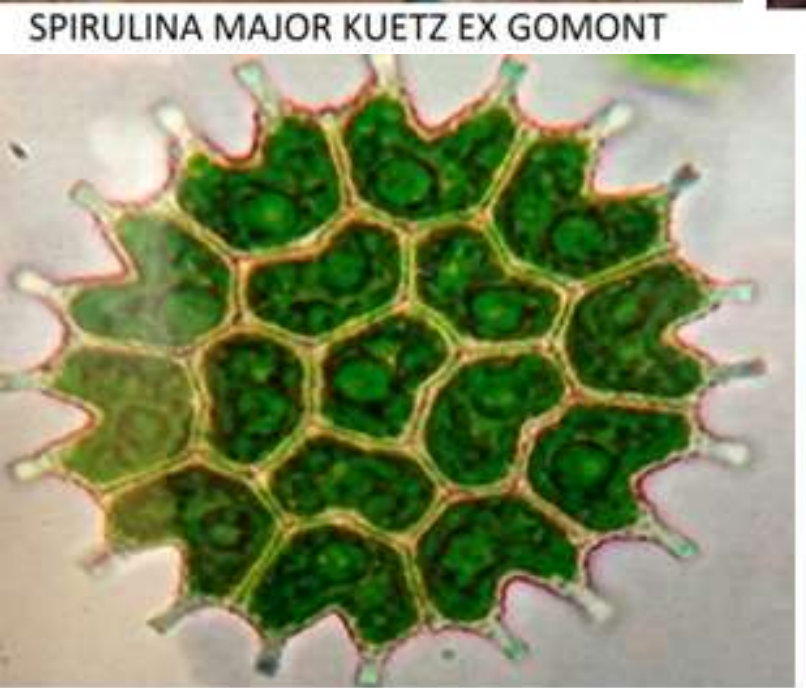

PEDIASTRUM BORYANUM(TRUP,) MEHEGHINI

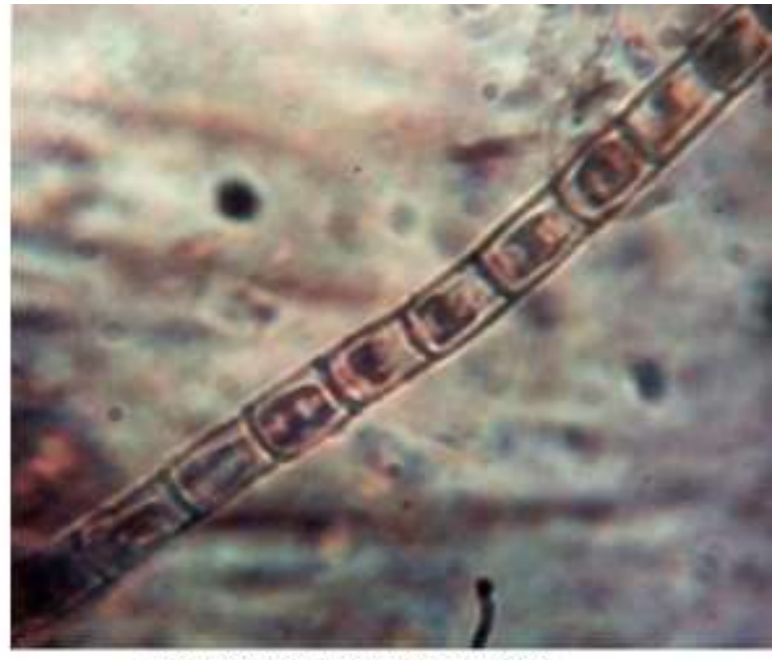

ULOTHRIX SUBTITIUSIMA RADENHORTS

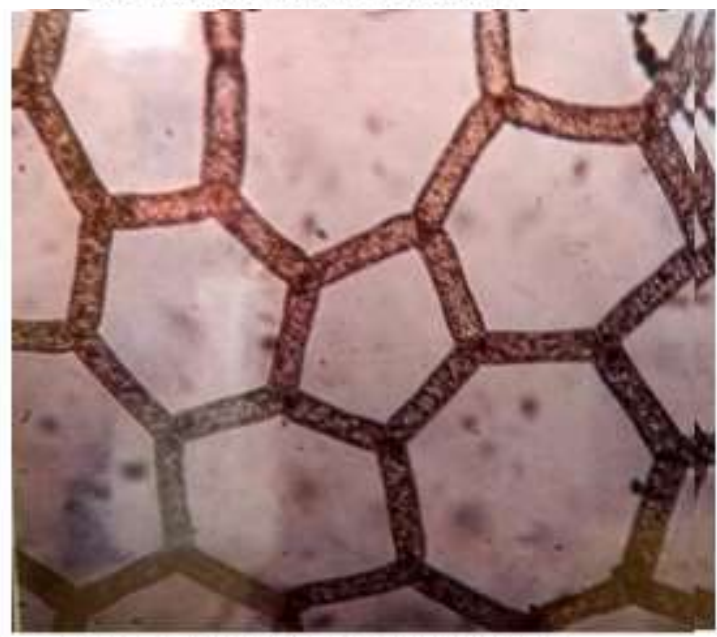

HYDRODICTYON RETICULATUM L. LAGERHEIM

Volume 6 Issue 12, December 2017 www.ijsr.net

Licensed Under Creative Commons Attribution CC BY 